
імені гетьмана Петра Сагайдачного ORCID 0000-0003-1452-6743

DOI 10.33099/2617-1775/2019-01/197-203

\title{
ЕФЕКТИВНЕ СПІЛКУВАННЯ ЯК ЗАПОРУКА УСПІШНОЇ ДІЯЛЬНОСТІ ОФІЦЕРА - ВІЙСЬКОВИКА
}

У статті обтрунтовано сутність ділового спілкування як одного з пріоритетних аспектів комунікативної культури військового офіџера. Окрему увагу приділено аналізові тих інтерактивних форм, які доцільно використовувати у прочесі навчання різних видів ділового спілкування при викладанні української мови за професійним спрямуванням у вищому військовому навчальному закладі.

Ключові слова: комунікативна культура; ефективне спілкування; інтерактивні форми; рольова гра.

Постановка проблеми.Ділове спілкування $є$ одним 3 головних видів взаємодії офіцера-військовика зі своїм керівництвом, зі своїми підлеглими, 3 колегами, 3 певними цивільними установами чи окремими особами у процесі здійснення ним своїх професійних обов'язків. Його ефективність визначається розвиненістю комунікативної культури учасників спілкування i, насамперед, самого офіцера. Комунікативна культура $\epsilon$ складовою загальної культури особистості офіцера, де комунікативність, емпатія, вміння спілкуватися у військовому середовищі, доступність спілкування, дозволяють уникненню конфліктів, підвищують рівень поваги з боку колег та підлеглих і є невід'ємним показником готовності виконувати покладені на нього обов’язки.

Аналіз нових досліджень цієї проблеми. Проблема формування комунікативної культури особистості майбутнього фахівця є багатоаспектною $\mathrm{i}$ становить предмет дослідження філософських, психологічних, педагогічних, лінгвістичних наук.Так, у новітньому науково-педагогічному інформаційному просторі представлені різні підходи до трактування поняття «комунікативна культура»: методологічний (О.В.Бондаревська, Н.В.Кузьміна, В.О. Слостьокін, Г.І. Щукіна та ін.), світоглядний (В.О. Ананьїн, В.Ф. Ломов та ін.), психологічний (В.Г. Ананьєв, Г.М. Андреєва, І.О. Зимняк, І.Б. Котова, О.О. Леонтьєв та ін.), соціологічний (Т.М.Дрідзе, С.І.Семигін, Є.В. Руденський та ін.), лінгвістичний (Б.М.Головін, К.Б.Пасько, I.К. Михольська та ін.), мовознавчий (П.М. Сршов, О.О. Мурашов та ін.), адаптивний (В.Т. Ащепков, Г.М. Якушева та ін.). духовний (О.I. Солженіцин, Е.П. Соколов та ін.).

Водночас мусимо констатувати, що недостатньо дослідженими залишаються прикладні аспекти комунікативної культури фахівця.

Мета статті.Розглянути сутність ділового спілкування як один 3 пріоритетних аспектів комунікативної культури військового офіцера. Простежити як формуються уміння та навички окремих видів ділового 
спілкування у процесі викладення дисципліни «Українська мова за професійним спрямуванням» в умовах ВВНЗ, проаналізувати інтерактивні засоби, які при цьому використовуються.

Методи дослідження.У даній статті застосовані елементи теоретичного, дидактичного, аналітико-описового та оглядового методів дослідження.

Виклад основного матеріалу. Марк Тулій Цицерон - видатний римський політичний діяч, філософ, письменник і один з найвеличніших ораторів світу якось сказав: «С два мистецтва, які можуть піднести людину на найвищий щабель пошани: одне - це мистецтво умілого полководця, друге - мистецтво доброго оратора». Наш час і реалії змінили акценти: пошану здобуває той командир, який вміє i може вплинути на своїх побратимів по зброї професійними знаннями і переконувальним словом.

Учасники неоголошеної війни Росії проти України, зокрема ті, які зараз навчаються в Національній академії сухопутних військ імені гетьмана Петра Сагайдачного, свідчать, що бойовий дух вселяє і підтримує у своїх підлеглих той офіцер, який вміє налагодити особистісні стосунки зі своїм підрозділом. Той, хто вміє побачити у кожному з воїнів особистість, доброзичливо до них ставиться.

Командир будь-якої військової ланки має бути не просто мовцем, а володіти належною мовною та мовленнєвою культурою. Тобто має уміти обрати й підтримати для досягнення професійної мети найбільш адекватний у конкретній ситуації стиль спілкування.

Ці компетенції майбутні офіцери-військовики здобувають під час навчання у своїй Almamater-військовій академії. I, перш за все, на зайняттях з навчальної дисципліни «Українська мова за професійним спрямуванням». Саме їй серед інших гуманітарних предметів належить пріоритетна роль. Адже вона, як жодна з інших, сприяє засвоєнню та виявленню знань з усіх фахових предметів, а пізніше доведенні їх до підлеглих вже у практичній сфері.

Навчальна дисципліна «Українська мова за професійним спрямуванням» у ВВНЗ має свої специфічні особливості, які випливають 3 тих завдань, які має виконувати офіцер у військах. Так, програма навчальної дисципліни у військовій академії побудована за кредитномодульною системою. У ній виокремлено чотири змістові модулі: «Основи фахового мовлення», «Сучасний діловий документ», «Основи риторики», «Ораторське мистецтво».

Останній 3 них якраз найбільш практично-фахово спрямований. У його межах майбутні військові офіцери опановують уміння та здобувають первинні навички, як виголосити промови різних типів, а перед цим їх укласти. Бути обізнаним 3 різноманітними формами ділового спілкування. Знати, як результативно провести службову нараду чи бесіду зі своїми підлеглими. Стати 3 користю для справи та іміджу своєї установи дієвим учасником зустрічі 3 представниками ЗМІ. Володіти коректними навичками ведення розмови зі стаціонарного чи мобільного телефонів тощо.

Разом $з$ тим військова сфера, як і будь-яка інша, дає грунт для суперечок. Життя показує, що не завжди учасники суперечок можуть гідно себе 
представити. Не вміють грамотно i толерантно розкритикувати точку зору опонентів. Не здатні чітко й зрозуміло висловити свою позицію, побудувати аргументацію. А, отже, переконати особу, з якою довелося посперечатися. Усі ці види усної комунікації залежать від уміння (чи невміння) застосовувати можливості ділового спілкування.

Бо як учень і вчитель є основними суб'єктами шкільної освіти і взаємодіють на рівні слова, так офіцер-військовик i його підлеглий мають взаємодіяти на рівні слова, за допомогою слова, через слово. Багато конфліктів у військовому середовищі, які часто закінчуються великою бідою, починаються 3 невміння офіцера-командира спілкуватися зі своїми підлеглими. Прикро й боляче вже у ХХІстолітті жити в стихії мовленнєвого безкультур'я військовиків: спостерігати й чути тяжковустих офіцерів високих посадових рівнів, уболівати душею за мовні покручі деяких військових викладачів, бачити окремі рецидиви «антириторики» офіцерів середньої ланки, які не можуть ефективно спілкуватися зі своїми підлеглими.

«Великий тлумачний словник сучасної української мови» пояснює, що спілкування $\epsilon$ «сукупністю взаємодій людей, спільнот, у яких відбувається обмін інформацією, вмінням та навичками, досвідом і результатами життєдіяльності». [2,1172]. Спілкування ж у військовому середовищі - це особливий вид спілкування, що $є$ категорією професійною. Це спілкування завжди навчальне, розвивальне та виховне. Адже спрямоване на розвиток особистостей, що спілкуються.

Командир будь-якого рівня та його підлеглий спілкуючись, організовують свою діяльність, обмінюються інформацією, звертаються один до одного 3 проханням, вимогою, подякою, тощо. Спілкування означає підтримання стосунків, діловий зв'язок, об'єднання для спільних дій, а це можливе лиш за умов відповідної культури мовлення офіцера. Не можна не погодитись 3 думкою Ольги Грейліх [3, 40-41], яка стверджує, що найважливішим компонентом комунікативної культури $\epsilon$ вільне володіння мовою. А воно припускає: грамотність, наявність великого запасу слів, образність, точність i доступність висловлювань, логічну послідовність. Важливо додати, що необхідно аби офіцер-командир ставився до колег (як по горизонталі, так і по вертикалі), не тільки як до засобу вирішення професійних завдань чи досягнення власного добробуту, але і бачив в інших партнерів по взаємодії, співрозмовників і поважав їхню гідність.

Цього можна досягти на заняттях 3 української мови за професійним спрямуванням, використовуючи ті форми навчання, які передбачають центризм того, хто навчається, повагу до його думки, спонукання до активності, заохочення до творчості. У працях зарубіжних педагогів цей підхід до навчання має назву «навчання за методом участі», «кооперативного навчання» [4, 221]. коли створюється можливість обговорення складових навчальної проблеми, доведення, аргументація власного погляду. Як обгрунтовує дослідниця цієї проблеми О. Василенко, «це сприяє не лише глибшому розумінню навчального матеріалу, а й розвитку мислення, аналітизму та мовлення» [1, 347]. 
У навчальній програмі «Українська мова за професійним спрямуванням» у ВВНЗ передбачені практичні заняття у формі рольової гри. «Термінологічний словник інженерно-педагогічної освіти» визначає іiі як «розважальнонавчального характеру, в якій учасники приймають певні ролі та колективно створюють історію або слідують уже наявній, у видуманих ситуаціях, діючи відповідно до своїх ролей»[5,142]. В умовах ВВНЗ курсанти створюють ситуацію, пов'язану зі своїм військовим фахом, діють, спілкуються у відповідності у обраних ролей.

Одне з практичних занять відбувається у формі рольової гри «Службова нарада». Оскільки нарада у середовищі військових $є$ одним з найефективніших способів обговорення важливих питань і прийняття рішень.Вона дає змогу аналізувати питання, висловлювати свої думки i пропозиції, приймати найоптимальніші рішення.

На лекції викладач оглядово характеризує різні види ділового спілкування: ділові бесіди, службові розмови зі стаціонарного та мобільного телефонів, зборів, дискусій, доповідей, переговорів тощо. Розповідає, зокрема, про сутність службової наради, вимоги до ії організації та проведення.Підкреслює, що нарада дає можливість кожному з їі учасників висловлювати свої думки 3 обговорюваної теми.

Під час самостійної підготовки курсантська група, наприклад, з тридцяти осіб, поділяється на три окремі підгрупи і готує «службову нараду» за темами, які запропонував викладач чи пропонує свої. Як правило, курсанти обирають теми, які безпосередньо пов'язані з їхнім військовим фахом. Популярними є: «Підготовка до польового виходу», «Участь батареї у добовому наряді», «Участь курсу у міжнародних військових навчаннях» та ін. Ті курсанти, які брали участь в Операції об'єднаних сил, а ще раніше, в АТО пропонують питання суто воєнні. Зацікавлення i активність викликають ті імітовані службові наради, на яких обговорюються питання зайняття того чи іншого населеного пункту Донбасу, постачання зброї та продовольства у зону бойових дій, контроль за здійсненням пересування цивільних осіб на перехідних пунктах тощо.

Під час самого практичного заняття «Службова нарада» кожній 3 груп надається визначений час для імітації обраної теми. Її учасники висловлюються, задають питання, відповідають на питання, поставлені своїми товаришами, у відповідності до прийнятих ролей. Інші дві групи слухають, спостерігають і занотовують, а по завершенні виступугрупи вони висловлюють свої враження, зазначають помічені неточності, пропонують свої варіанти того чи іншого висловлювання. Якщо узагальнено $\square$ відбувається діяльне ділове спілкування.

Звичайно, така форма навчання потребує контролю як з боку викладача, так і 3 боку курсантів щодо себе i своїх товаришів. Проте поступово викристалізовується, як активно відбувається засвоєння ними нових знань, закріплення їх та формування умінь і навичок мовленнєвої культури службової 
наради i, найголовніше, поступове долання «бар'єру страху» промовляти публічно.

Досвід показує, що подібні інтерактивні форми навчання сприяють викладачеві виявленню творчих можливостей своїх вихованців і, в цілому, посилюють інтерес до української мови. Доказом цього може послужити те, що в Національній академії сухопутних військ імені гетьмана Петра Сагайдачного, де вчаться вихідці зі всієї України останніми роками набув популярності конкурс «Сила слова». Метою цього позааудиторного закладу $є$ не просто визначити кращого оратора-курсанта, а, так би мовити , ще раз, на практиці, переконати наших вихованців, що командир-військовик повинен окрім спеціальних знань ще й володіти цілим арсеналом умінь переконувального спілкування.

Для участі у конкурсі кожен факультет Академії представляє трьохчотирьох учасників. Під час підготовки цим курсантам пропонуються різні теми виступів: «Звернення командира підрозділу до тих, хто вперше візьме участь у бою», «Розмова командира 3 підлеглими у різдвяний вечір в окопі», «Слово командира перед тими, хто відслужив на передовій», «Промова командира при прощанні зі загиблим побратимом» та ін.

Кращі виступи на конкурсі демонструють, що майбутні офіцеривійськовики можуть не тільки промовляти змістовно, яскраво та емоційно, але й уміють спланувати своє мовлення 3 підлеглими i колегами, знаходити правильну форму звертання до них, виявляти особисту прихильність до своїх слухачів, зрештою, уміють керувати спілкуванням.

Подібні позааудиторні заходи логічно продовжують і закріплюють вивчене під час плановихзанять 3 української мови за професійним спрямуванням. Сприяють піднесенню соціального престижу державної мови i, водночас, $\epsilon$ підтвердженням того, що вона серед військовиків стає все більше затребуваною, а майбутні офіцери можуть стати пропагандистами української мови.

Висновки. Підсумовуючи вище викладене, слід зазначити, що спілкування у практиці військового офіцера $є$ чи найголовнішим засобом досягнення професійної мети. Тому в процесі викладання дисципліни «Українська мова за професійним спрямуванням» цей аспект комунікативної культури має стати пріоритетним.

Відтак, вбачаємо завдання викладача цього предмета впроваджувати на заняттях ті форми i методи, які забезпечують вияв творчих можливостей вихованців, допомагають їх активному інтелектуальному розвитку, усвідомленому засвоєнню лінгвістичних понять, сформуванню мовленнєвої культури та морально - вольових якостей, а також, вихованню активної мовної особистості.

Перспективним видається подальше дослідження тих інтерактивних форм, які би удосконалювали комунікативну культуру майбутніх офіцерів військовиків. 


\section{ЛІТЕРАТУРА}

1. Василенко О.П. Застосування засобів інтерактивних технологій навчання при викладанні української мови за професійним спрямуванням майбутнім фахівцям інженернотехнічних спеціальностей / О.П. Василенко // Наукові праці Кам'янець-Подільського національного університету ім. Івана Огієнка: Філологічні науки. - 2017. - Вип. 44. - с. 347 349.

2. Великий тлумачний словник української мови (з дод. і допов.) / Укладач і головний редактор В.Т. Бусел. - К.: Ірпінь: ВТФ “Перун”, 2005. - 1728 с.

3. Грейліх О. Комунікативна культура як компонент педагогічної культури викладача вищого навчального закладу / Ольга Грейліх // Психолінгвістика. - 2012, вип. 9. - с. 38-42.

4. Кошманова Т.С. Розвиток педагогічної освіти у США (1960-1988 рр.) / Т.С. Кошманова . - Львів: Світ, 1999. - 486 с.

5. Курок В.П. Термінологічний словник інженерно-педагогічної освіти / В.П. Курок // Глухівський педагогічний університет ім. О. Довженка. - 2014. - 348 с.

\section{REFERENCES}

1.Vasylenko, O.P. (2017). Zastosuvannia zasobiv interaktyvnykh tekhnolohii navchannia pry vykladanni ukrainskoi movy za profesiinym spriamuvanniam maibutnim fakhivtsiam inzhenernotekhnichnykh spetsialnostei [Using of the interactive forms duringthe teaching process ofUkrainian language for professional purpose for the future specialists in technical engineering] Naukovi pratsi Kamianets-Podilskoho natsionalnoho universytetu imeni Ivana Ohiienka : Filolohichni nauky. Vyp. $44-347-349$ s. (in Ukrainian)

2. Busel, V.T. (2005). Velykyy tlumachnyi slovnyk suchasno iukrainskoi movy [Big Ukrainian explanatory dictionary ] Kyiv: «Perun»,1978 s. (in Ukrainian)

3. Hreilich, O. (2012). Komunikatyvna kultura yak komponen tpedahohichnoi kultury vykladacha vyschoho navchalnoho zakladu [Communicative culture as pedagogical culture component of the teacher of The higher education institution] Psykholinhvistyka, vyp. 34-42 s. ( in Ukraine)

4. Koshmanova, T.S. (1999). Rozvytok pedahohichnoi osvity v USA (1960-1998) [Development of the pedagogical education in the USA] Lviv: Svit, $1999-486$ s. ( in Ukrainian)

5. Kurok, V.P. (2014). Terminolohichnyi slovnyk inzhenerno-pedahohichnoi osvity [Terminological dictionary of pedagogical engineering education] Hlukhivskyi pedahohichnyi universytet imeni O.Dovzhenka. 348 s.(inUkrainian)

\section{РЕЗЮМЕ}

Клавдия Панасюк,

кандидат филологических наук, доцент Национальная академия сухопутных войск имени гетьмана Петра Сагайдачного

\section{Эффективное общение как залог успешной деятельности военного офицера}

В статье рассмотрена сущчность делового общения как один из приоритетных аспектов коммуникативной культуры военного офицера. Автор исследования обосновывает мнение, что именно деловое общение является одним из главных видов взаимодействия офицера со своим руководством, со своими подчинёнными, с коллегами, с определёнными гражданскими учреждениями или отдельными личностями в процессе выполнения им своих профессиональных обязанностей.

В работе прослеживается на конкретных примерах как формируются умения $и$ навыки отдельных видов делового общения в прочессе обучения учебной дисииллины "Украинский язык по профессиональной направленности" в условиях высшего военного 
учебного заведения. Охарактеризованы интерактивные формы, которые целесообразно при этом использовать.

Ключевые слова: коммуникативная культура; эффективное общение; интерактивные формы; ролевая игра.

\title{
SUMMARY
}

\author{
Klavdya Panasiuk, \\ Candidate of philological sciences, associate professor \\ The National Army Academy \\ named after hetman Petro Sahaidachnyi
}

\section{In the article it is considered the essence of business communication as one of the officer communicative culture priorities}

Introduction.The author of research substantiates her opinion on business communication that is on of the main type of cooperation between officer and his commanders, subordinates, colleagues, civilians during carrying out his professional duties.It's effectiveness is determinated by communicative culture skills of the participants, and and first of all for the officer. Communicative culture is a component of general culture of the officer's personality. The level of respect for the officer from colleagues and subordinates is increased by his self communicative skills, empathy, ability to communicate in the military environment and accessibility of communication. Also that allows to avoid conflicts and is an indicator of the readiness to perform his duties.

The problem of forming self communicative culture of the future specialist is multifaceted problem and is the subject of the philosophical, psychological, pedagogical and linguistic researches.

Purpose.Applications of specialist's communicative culture are insufficiently researched.Therefore the objective of the article is the essence of business communication analyze as the most important component of the officer's communicative culture. To examine on the case studies the process of skills and abilities formation of business communication types during the teaching discipline " Ukrainian language for professional purpose" in The higher military institutions and to characterized interactive forms that are appropriated.

Methods.There were used different methods of research such as: theoretical, deducting, descriptive analytical and observation.

Results.This article demonstrates that business communication is one of the main methods in the officer practice to achieve professional goals of leadership, education and training his subordinates.

Originality.The forms for providing development of subordinates creative possibilities and support the formation of the linguistic personality.

Conclusion.That's why they should use special forms for developing creative possibilities of the subordinates duringthe teaching process ofUkrainian language for professional purpose and support the formation of the linguistic personality.

Further researches of the interactive forms are prospective as they improve communicative culture of the future officers.

Key words: communicative culture; effective communication; interactive forms; role play. 